\title{
PENDAMPINGAN MANAJEMEN PEMASARAN DENGAN MEMANFAATKAN IPTEKS PADA USAHA MIKRO, KECIL DAN MENENGAH (UKM) TERDAMPAK COVID-19
}

\author{
Rismawati ${ }^{1)}$, Zikra Supri1), I Ketut Patra3) \\ ${ }^{1)}$ Akuntansi, Fakultas Ekonomi dan Bisnis, Universitas Muhammadiyah Palopo, Palopo, Sulawesi Selatan, Indonesia \\ ${ }^{2}$ )Imu Ekonomi, Fakultas Ekonomi dan Bisnis, Universitas Muhammadiyah Palopo, Palopo, Sulawesi Selatan, Indonesia \\ Corresponding author : Rismawati \\ E-mail : risma11@umpalopo.ac.id
}

Diterima 11 Oktober 2021, Direvisi 15 Desember 2021, Disetujui 15 Desember 2021

\begin{abstract}
ABSTRAK
Pandemi Covid 19 berdampak pada perubahan tatanan bersosialisasi, berbisnis dan bermasyarakat. Kelompok masyarakat yang lebih kecil seperti pelaku UKM juga mengalami dampak perubahan tersebut; sehingga memerlukan bimbingan khusus untuk beradaptasi dengan kondisi yang baru. Beberapa kendala dan masalah yang muncul diantaranya adalah berkurangnya omset pelaku UKM yang disebabkan karena keterbatasan dalam melakukan inovasi dan manajemen produksi. Tujuan dari program pengabdian ini adalah meningkatkan daya saing UKM. Terselenggaranya program ini merupakan bagian dari tridharma perguruan tinggi yaitu pengabdian kepada masyarakat dan bentuk tindak kerjasama yang dilakukan universitas dengan Sentra UKM Barambing Kabupaten Luwu yang bertindak sebagai mitra. Beberapa kegiatan yang dilakukan dalam program ini diantaranya; pelatihan digital marketing, pelatihan Pembuatan laporan keuangan dalam bentuk modul /format praktis serta pelatihan diversifikasi dan inovasi produk (desain produk). Luaran yang dihasilkan dalam program ini, adalah terlaksananya kegiatan pelatihan yang berdampak terbukanya peluang pasar online sehingga pemasaran produk UKM meningkat; pemahaman dan kemampuan peserta pelatihan dalam menyusun laporan keuangan; pengembangan luaran produksi dengan tampilan yang lebih menarik. Penguatan pada tiga komponen ini dapat meningkatkan omset UKM Barambing Kabupaten Luwu dalam jangka Panjang.
\end{abstract}

Kata Kunci : UKM; covid-19; inovasi; pengabdian.

\begin{abstract}
The Covid-19 pandemic has impacted changes in socializing, doing business, and socializing. Smaller community groups such as SMEs are also affected by these changes, requiring exceptional guidance to adapt to new conditions. Some of the obstacles and problems that arise include SMEs' reduced turnover due to limitations in innovation and production management. The purpose of this service program is to increase the competitiveness of SMEs. The implementation of this program is part of the tri dharma of higher education, namely community service and a form of cooperation carried out by the university with the Barambing SMEs Center, Luwu Regency, which acts as a partner. Some of the activities carried out in this program include; digital marketing training, training on making financial reports in the form of practical modules/formats, and training on product diversification and innovation (product design). The outputs produced in this program are the implementation of training activities that impact opening online market opportunities so that SME product marketing increases; understanding and ability of training participants in preparing financial reports; production output development with a more attractive appearance. Strengthening these three components can increase the turnover of Barambing SMEs in Luwu Regency in the long term.
\end{abstract}

Keywords: SMEs; covid-19; innovation; devotion.

\section{PENDAHULUAN}

Saat ini perekonomian global termasuk Indonesia mengalami ketidakpastian dan mengarah pada resesi ekonomi karena pandemi Covid-19 (Iswari \& Muharir, 2021). Perlambatan ekonomi pasti akan berdampak pada kinerja pertumbuhan ekonomi Indonesia pada tahun 2020. Pandemi menimbulkan efek domino dari kesehatan ke masalah sosial dan ekonomi (Arianto, 2021).

Kondisi perekonomian selama pandemi covid-19 merupakan hal sangat dikhawatirkan oleh semua pihak. Meskipun virus ini merupakan masalah kesehatan akan tetapi 
dampak yang dihasilkan mempengaruhi sebagian besar pelaku ekonomi, temasuk diantaranya Usaha Mikro, Kecil dan Menengah (UMKM). Beberapa tahap kebijakan pemerintah dalam bentuk Pembatasan Sosial Berskala Besar (PSBB) yang akhirnya meningkat, menjadi Pemberlakuan Pembatasan Kegiatan Masyarakat (PPKM) berjenjang, mulai dari level 4 adalah pembatasan paling ketat. Pilihan untuk melanjutkan hidup berdampingan dengan virus dikenal dengan istilah new normal life (Muhyiddin, 2020).

New normal tidaklah sama dengan kondisi dengan keadaan normal biasa, terdapat beberapa kebiasaan dan peraturan yang tentunya butuh waktu dan penyesuaian. Muhyiddin (2020) menjelaskan dampak pandemi pada sektor ekonomi yang dirasakan oleh Usaha Mikro Kecil Menengah (UMKM). UMKM sebagai salah satu pilar penting dalam perekonomian Indonesia, mengalami kerugian dan menjadi stagnan. Secara global UMKM saat ini berada dalam pusat krisis sebagai dampak dari pandemi covid-19, kondisi ini bahkan lebih parah dari krisis keuangan pada tahun 2008 (Nabilah et al., 2020). Resiko paling serius yang dapat terjadi yaitu krisis akan berpengaruh pada UMKM dan lebih dari $50 \%$ tidak akan bertahan beberapa bulan ke depan (OECD, 2020).

Salah satu persoalan terbesar yang dirasakan oleh UMKM adalah dampak penurunan penjualan. Dampak pandemi terhadap UMKM diyakini dapat lebih besar, karena tingginya tingkat kerentanan dan minimnya ketahanan akibat keterbatasan sumber daya manusia, supplier, dan opsi dalam merombak model bisnis (Sugiri, 2020). Kondisi ini tentunya membutuhkan penanganan khusus untuk mencegah dan mengurangi resiko yang semakin parah. Kami tim dosen pengabdi melakukan survey untuk mengetahui akar masalah yang dihadapi oleh UMKM yang tergabung dalam sentra UKM Barambing.

Sentra UMKM Barambing di Kabupaten Luwu merupakan sebuah Pusat Usaha Mikro Kecil dan Menengah (UMKM) yang didirikan dengan tujuan dapat meningkatkan pertumbuhan ekonomi dan meningkatkan kesejahteraan masyarakat Luwu (Kabupaten Luwu, 2019). Pusat UMKM ini merupakan bagian dari Dinas Koperasi UMKM dan Perindustrian Kabupaten Luwu. Sentra ini berfungsi sebagai galery produk, tempat pemasaran serta pusat oleh oleh di kabupaten Luwu. Area ini juga menyediakan berbagai macam fasilitas seperti musholla, toilet, kopi gratis untuk sopir, karaoke gratis dan politeknik kesehatan.
Sebanyak kurang lebih 30 produksi rumahan yang dari berbagai daerah di kabupaten Luwu menjadi bagian di galery Sentra UMKM Barambing ini. Produk yang dipasarkan merupakan produk usaha rumahan serta menengah yang berbasis pangan contohnya kue-kue tradisional, ada juga olahan kayak kopi, olahan kayu secang. Namun selain memasarkan produk dari UKM lain tempat ini juga menjadi sentra produksi bebrapa produk seperti kopi, sagu kering dan bagea. (Manaf Abdi, 2021).

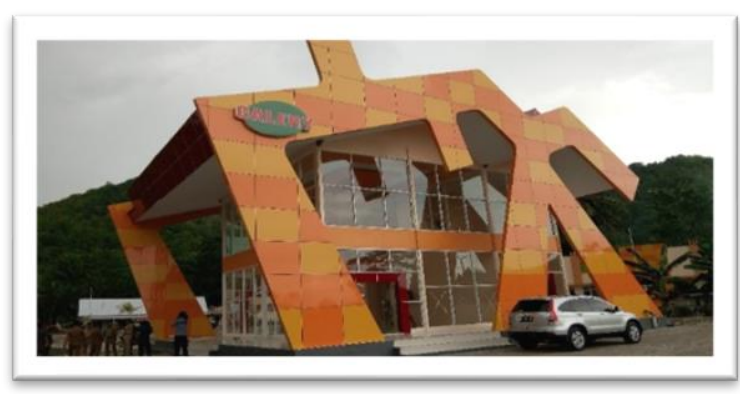

Gambar 1. Sentra UMKM Barambing

Pemilihan mitra ini didasarkan pada kerjasama yang telah dilakukan sebelumnya antara Perguruan Tinggi dengan Sentra IKM Barambing melalui Dinas Koperasi UKM dan Perindustrian Kabupaten Luwu. Kegiatan ini tentunya menjadi tindak lanjut dari perjanjian kerjasama tersebut. Target kegiatan untuk program ini adalah pelaku UKM yang terdampak covid-19, sehingga Mitra UMKM Barambing bertindak sebagai penghubung bagi pelaksana kegiatan (pelaksana) dengan UKM. Selain itu Sentra UMKM juga membantu dalam pelaksanaan kegiatan ini khususnya dalam penyediaan sarana dan prasarana pelaksanaan kegiatan.

\section{METODE}

Kegiatan ini merupakan salah satu bentuk transfer ilmu pengetahuan dan teknologi (Iptek) yang dilakukan oleh akademisi kepada pelaku UKM yang membutuhkan. Kegiatan ini terdiri dari dua tahapan antara lain tahap persiapan dan tahap pelaksanaan. Berikut bagan alur kegiatan pengabdian.

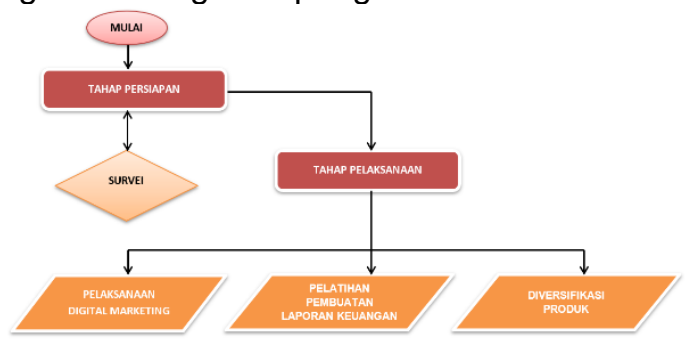

Gambar 2. Bagan Alur Pengabdian 


\section{Tahap Persiapan}

Tahap ini merupakan tahap awal dimana pelaksana melakukan survey pendahuluan untuk memastikan program yang sesuai dan dibutuhkan oleh pelaku UMKM yang terdapat di sentra UMKM Barambing. Forum Discussion Group (FGD) dilakukan antar tim dosen pengabdi dengan pelaku UKM dan Dinas terkait. FGD dilakukan sebagai upaya need asessment dan penyamaan presepsi dan tujuan kegiatan. Pada tahap ini di simpulkan bahwa masalah yang dihadapi oleh UMKM adalah berkurangnya omset penjualan karena covid serta keterbatasan dalam melakukan pemasaran produk, inovasi produk dan manajemen produksi.

Hasil survei kami petakan dalam bentuk pokok-pokok masalah yang dihadapi oleh pelaku UMKM, diantaranya adalah:

1. Pelaku UMKM hanya memasarkan produknya pada store yang telah disediakan oleh permerintah daerah, maupun pada kios atau toko milik pribadi.

2. Model pemasaran produk masih konvensional yang diistilahkan sebagai "sistem menunggu bola" dimana para penyedia produk pasif menunggu pembeli.

3. Para pelaku UMKM kesulitan mendapat bantuan dari Bank karena tidak memiliki informasi keuangan aktivitas bisnis mereka.

4. Desain produk dan kemasan cenderung monoton sehingga tidak memiliki daya tarik bagi konsumen milenial.

\section{Tahap Pelaksanaan}

Dari hasil need assessment pada tahap persiapan telah diketahui pokok permasalahan yang dihadapi oleh masyarakat. Keempat permasalahan tersebut di atas semakin diperparah dengan adanya covid-19, mobilitas masyarakat sangat terbatas, sehingga model pemasaran poduk secara konvensional mengalami mati suri. Covid-19 memaksa semua pihak untuk berpikir lebih kreatif agar dapat survive; sehingga kami tim dosen pengabdi memetakan solusi permasalahan tersebut dengan program:

\section{a. Pelatihan dan Pendampingan Digital Marketing}

Pemasaran online atau sering disebut sebagai pemasaran digital diartikan sebagai strategi pemasaran yang memanfaatkan internet. Kegiatan pemasaran untuk mendapatkan perhatian konsumen dilakukan dengan memanfaatkan media sosial, website, serta media jual beli online lainnya yang tersedia. Selain pelatihan kami melakukan pendampingan selama 2 (dua) bulan terhitung sejak bulan Juli, dengan melakukan kunjungan setiap minggu. Indicator capaian kegiatan ini adalah para pelaku UMKM dapat memanfaatkan social media untuk memasarkan produknya. Nama usaha memiliki akun bisnis pada platform Instagram, Shopee, TokoPedia.

b. Pelatihan Pembuatan laporan keuangan (Modul /Format Praktis) dan Pendampingan.

Salah satu kendala yang dihadapi UMKM adalah kesulitan akses keuangan kepada lembaga keuangan yang disebabkan penerapan manajemen pengelolaan usaha/keuangan UMKM yang belum profesional, khususnya mengenai pencatatan transaksi keuangan dan penyediaan laporan keuangan. Kegiatan ini juga memberikan pelatihan pembuatan laporan keuangan, serta perhitungan harga pokok produk sederhana. Tim Dosen Pengabdi melibatkan empat orang mahasiswa untuk melakukan pendampingan selama dua bulan dengan kunjungan perminggu. Indicator capaian dari kegiatan ini adalah para pelaku UMKM memiliki catatan aktivitas bisnis (sederhana) seperti catatan aliran arus kas yang dapat diperlihatkan kepada pihak yang berkepentingan.

c. Diversifikasi Produk

Diversifikasi produk yaitu upaya mencari dan mengembangkan produk atau pasar yang baru, atau keduanya, dalam rangka mengejar pertumbuhan, peningkatan penjualan Pemberian saran atau pilihan kepada mitra untuk melakukan diversifikasi produk dengan mengajukan beberapa jenis barang yang bisa mereka produksi. Untuk poin ini Tim Dosen Pengabdi melibatkan empat orang mahasiswa untuk mendapingi program ini. Kami lebih mengandalkan youtube untuk mengembangkan ide diservikasi produk. Indikator capaian dari kegiatan ini adalah para pelaku UMKM mempunyai desain produk yang baru.

\section{HASIL DAN PEMBAHASAN}

Kegiatan pelatihan dilakukan selama satu hari dalam bentuk workshop dan melakukan pendampingan selama dua bulan terhitung mulai bulan Juli hingga awal September. pendampinga kurang lebih satu bulan dengan pelaksanaan kegiatan selama 1 hari dengan peserta kegiatan sebanyak 16 orang. Materi untuk setiap kegiatan dibagi persesi dan pendampingan selama 1 bulan. Sesi pertama merupakan pelatihan Digital Marketing, sesi kedua pelatihan pembuatan laporan keuangan (modul /format praktis) dan terakhir merupakan materi diversifikasi/inovasi produk. Berikut merupakan pembahasan untuk setiap kegiatan yang dilakukan. 


\section{Pelatihan Digital Marketing}

Sebagaimana tujuan awal
pelaksanaan program yaitu untuk meningkatkan daya saing usaha kecil menengah, oleh karena itu salah satu cara yang ditempuh melalui pemasaran produk yang lebih kreatif. Pelatihan ini menekankan pada bagaimana melakukan promosi pemasaran dengan memanfaatkan akses digital/online. Sehingga, selain melalui galeri sentra UMKM Barambing, produk juga dijual melalui platform digital dengan memanfaatkan media sosial. Materi Pelatihan ini diberikan oleh narasumber dalam bidang marketing digital. Pelatihan dimulai dengan pemberian materi yang selanjutnya dilanjutkan dengan sesi tanya jawab. Sesi ini berlangsung selama dua setengah jam yang direspon baik oleh peserta.

Tim Dosen menyadari pemberian materi pelatihan saja tidak cukup. Sehingga, sebagai tindak lanjut dari pelatihan adalah pendampingan secara intensif, yang dibagi menjadi kelompok-kelompok berdasarkan wilayah domisili peserta.

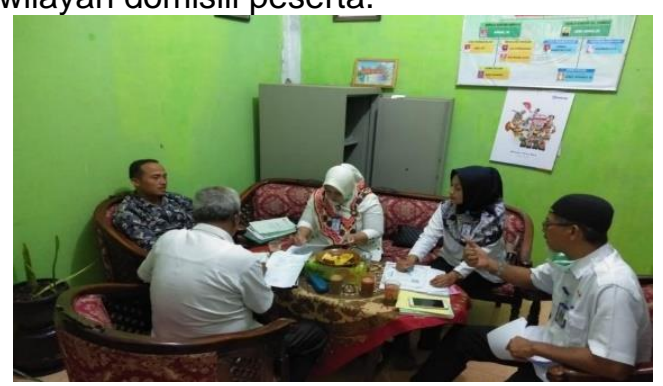

Gambar 3. Proses Pendampingan

\section{Pelatihan Pembuatan laporan keuangan (Modul /Format Praktis)}

Untuk pelatihan pembuatan laporan keuangan atau pencatatan keuangan sederhana, dilakukan dalam bentuk pendampingan. Sebelumnya peserta dikenalkan dengan bentuk laporan keuangan sederhana dalam bentuk modul kerja berupa jurnal percatatan, serta mendampingi untuk perhitungan laba rugi dan harga produk. Kegiatan ini didampingi oleh narasumber yang memiliki kompetensi bidang akuntansi yang dibantu oleh dua mahasiswa akuntansi yang berkompeten.

Pendampingan yang dilakukan selama dua bulan dengan durasi pertemuan 5 jam perminggu, memberikan hasil yang nyata. Masing-masing peserta telah memiliki catatan akuntansi untuk aktivitas bisinisnya. Hal ini akan mempermudah pihak internal maupun eksternal untuk memberikan penilaian, sehingga keuntungan dan kerugian dapat dianalisis.

\section{Diversifikasi dan Inovasi Produk}

Kegiatan ini merupakan pelatihan tambahan yang diberikan dalam bentuk materi tentang diversifikasi dan inovasi produk (desain produk) Para pelaku usaha yang selama ini memproduksi produk yang monoton dan tidak kreatif, diberikan saran untuk penembangan produk yang sesuai dengan kapasitas dan dibutuhkan oleh pasar. Baik dalam hal jenis ataupun pengemasan produk. Sesi ini juga dimulai dengan pemebrian materi yang dilanjutkan dengan diskusi/tanya jawab.

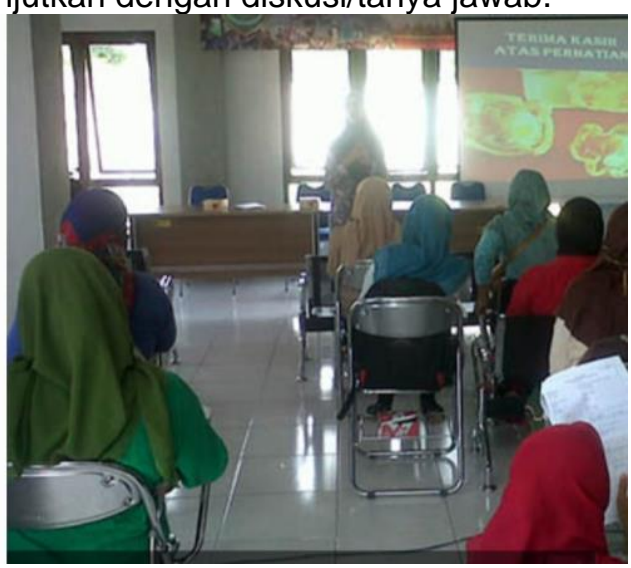

Gambar 4. Proses Pelatihan

\section{SIMPULAN DAN SARAN}

Program Pengabdian ini dilakukan sebagai upaya meningkatkan daya saing UKM khususnya yang terdampak covid-19. Pelaksanaan Kegiatan ini dilakukan dalam bentuk transfer Ilmu Pengetahuan (Iptek). Beberapa materi pelatihan yang diberikan antara lain pelatihan Digital Marketing, pembuatan laporan keuangan (modul /format praktis) dan materi diversifikasi dan inovasi produk (desain produk).

Manfaat yang dapat dirasakan secara langsung bagi seluruh peserta pelatihan adalah perserta pelatihan mulai memanfaatkan teknologi informasi dalam mempromosikan produknya melalui akun sosmed yang dimiliki. Pelaku UKM telah memiliki catatan keuangan bisnis yang dapat digunakan oleh pihak eksternal dalam menilai kinerja usahanya. Dan yang terakhir, terbangunnya ide-ide kreatif untuk hasil olahan produk, sehingga hasil produksi tidak terkesan monoton. Tim dosen pengabdi sangat optimis, kerjasama ini dapat meningkatkan kemampuan pelaku UKM di Sentra UKM Barambing untuk tetap survive dalam berusaha dimasa pandemi Covid-19. Sehingga, harapan agar omset penjualan para pelaku UKM dapat meningkat bukan suatu yang mustahil.

\section{UCAPAN TERIMAKASIH}

Tim dosen pelaksana pengabdian mengucapkan terima kasih kepada berbagai 
pihak yang ikut terlibat dan membatu dalam terlaksananya kegiatan ini. Terimakasih kami ucapkan kepada para peserta yang sangat antusias dalam mengikuti pelatihan dan pendampingan, sehingga kegiatan ini dapat terlakasana dengan baik. Terimakasih juga kami ucapkan kepada pengelola jurnal Selaparang yang bersedia mempublikasikan pengabdian kami.

\section{DAFTAR RUJUKAN}

Arianto, B. (2021). Dampak Pandemi COVID-19 terhadap Perekonomian Dunia. Jurnal Ekonomi Perjuangan, 2(2), 212-224. https://doi.org/10.36423/jumper.v2i2.665

Iswari, L. M. (2021). Pengaruh COVID-19 Terhadap Investasi di Indonesia. Jurnal Ilmiah Mahasiswa Ekonomi Syariah (JIMESHA), 1(1), 13-20. https://doi.org/10.36908/jimesha

Iswari, L., \& Muharir. (2021). PENGARUH COVID19 TERHADAP AKTIVITAS PERTUMBUHAN EKONOMI DI INDONESIA. Jurnal IImiah Mahasiswa Ekonomi Syariah, 1(1), 13-20.

Muhyiddin. (2020). Covid-19, New Normal, dan Perencanaan Pembangunan di Indonesia. Jurnal Perencanaan Pembangunan: The Indonesian Journal of Development Planning, 4(2), 240-252. https://doi.org/10.36574/jpp.v4i2.118

Nabilah, S., Nursan, M., \& Pande Komang Suparyana. (2020). Dampak Pandemi Covid-19 terhadap UMKM (Studi Kasus UMKM ZEA FOOD di Kota Mataram). Jurnal Inovasi Penelitian, 1(3), 1-4.

Kabupaten Luwu. (2019, February 14). Gubernur Sulsel Resmikan Pusat Industri Kecil dan Menengah (IKM) Barambing di Luwu. Portal Luwu.

Manaf Abdi. (2021, March 9). Sentra IKM Barambing Jadi Pusat Kuliner Oleh-oleh di Luwu. Kabar Makassar.

Mappong, S. (2021, March 4). Terdampak pandemi, 1.953 UMKM di Sulsel butuh peningkatan kapasitas. Antara.

OECD. (2020). Coronavirus (COVID-19): SME Policy Responses. https://www.wto.org/english/news_e/pres 20_e/pr858_e.htm

Sugiri, D. (2020). Menyelamatkan Usaha Mikro, Kecil dan Menengah dari Dampak Pandemi Covid-19. Fokus Bisnis: Media Pengkajian Manajemen Dan Akuntansi, 19(1), 76-86. https://doi.org/10.32639/fokusbisnis.v19i1 $\underline{.575}$ 